\title{
Impact of bidirectional relationships between streptococcus anginosus group and host tissue matrix components on cellular activity: role in establishment of infection
}

\author{
Rachel J Waddington ${ }^{1 *}$, Janine Landrygan-Bakri', Melanie J Wilson', David W Williams ${ }^{1}$ and Michael AO Lewis ${ }^{1}$ \\ *Correspondence: waddingtonrj@cardiff.ac.uk \\ 'Tissue Engineering and Reparative Dentistry, School of Dentistry, College of Biomedical and Life Sciences, \\ Cardiff University, Heath Park, Cardiff, CF14 4XY, UK.
}

\begin{abstract}
This paper investigates pathogenic mechanisms of the Streptococcus anginosus group (SAG) of bacteria which influence the biological activity of periodontal ligament (PDL) cells, endothelial cells and also how matrix proteins produced by these host cells influence bacterial virulence factors. Isolates of SAG species, designated S. anginosus, S. constellatus and S. intermedius, were derived from healthy commensal and clinical pathogenic infection sites. SAG culture supernatants contained multiple protein components which differed between isolates. All SAG supernatants increased cellular proliferation and decreased decorin synthesis and collagen assembly by PDL cells and reduced endothelial cell migration. SAG isolates responded differently to extracellular matrix (ECM) components synthesised by PDL cells, but there was an overall notable increase in hydrolytic enzyme activity and in the production of the cytotoxin intermedilysin by S. intermedius. Collectively, the results indicate that both commensal and pathogenic SAG isolates were capable of impairing the ability of PDL cells and endothelial cells to make functional vascularised tissue. Reduced decorin synthesis is likely to have a major impact on cell signalling, angiogenesis and matrix assembly. Furthermore, ECM components produced by PDL cells were differentially capable of moderately increasing SAG enzymic activity, leading to subtle ECM modifications. The impact this bidirectional effect has on the tissue remodelling process is discussed.
\end{abstract}

Keywords: Streptococcus anginosus group, periodontal ligament, mesenchymal cells, endothelial cells, decorin

\section{Introduction}

Members of the Streptococcus anginosus group (SAG) of microaerophilic bacteria can exist as part of the commensal microflora of the body, particularly within the oral cavity, or as pathogens in polymicrobial orofacial infections such as dentoalveolar and periodontal abscess [1-5] and thoracic infection, such as pneumonia, purulent emphysema and lung abscess [6]. Often described as pioneer microorganisms in the establishment of infection, it has been proposed that the SAG bacteria prepare the micro-environment for further colonisation by other anaerobic bacterial species $[7,8]$. SAG have a tendency for haematogenous spread leading to the establishment of deeper-seated infections such as brain and liver abscesses [9].

The periodontal ligament (PDL) consists principally of a type I and type III collagen fibre network, providing structural support and attachment of the tooth within its socket. The formation of these collagen fibres is regulated by decorin which is a small leucine rich proteoglycan, the $\mathrm{N}$ terminal of which is conjugated by one dermatan sulphate glycosaminoglycan chain $[10,11]$. Decorin has been demonstrated to interact with tropocollagen and guide lateral fusion in fibril formation in vitro $[12,13]$. Of note, targeted deletion of decorin in mice resulted in irregularly sized and shaped collagen fibril bundles, many with an over-large morphology, which was most evident in the PDL [14]. Decorin has also been proposed to influence cell signalling and proliferation of both PDL and endothelial cells either by direct binding to cell surface receptors [14-17] or by binding of growth factors in the matrix and regulating their release $[11,18]$. As a consequence of the constant physical forces placed on this tissue, collagens within the PDL have amongst the highest turn-over rates of all connective tissues within the body, [19] resulting in the constant renewal of the periodontal fibres, the alveolar bone proper and the anchoring Sharpey's inserts. Cells within the PDL are thus capable of a rapid response, facilitating an extremely high turnover of the extracellular matrix (ECM) proteins [20]. Within this scenario, mesenchymal progenitor cells within the PDL proliferate, migrate and ultimately differentiate, leading to the synthesis of new collagen fibres, orchestrated by proteins such as decorin. In addition, high proliferation of endothelial cells and angiogenesis in the PDL is apparent during these periods of repair, together with signalling factors such as vascular endothelial growth factor (VEGF) and prostaglandin $E_{2}$ from endothelial cells which are proposed to promote PDL progenitor cell osteogenesis [21]. Alterations to the biological activity of these cells would therefore have a sharp deleterious impact in maintaining a functional tissue.

In considering the establishment of infection, our previous studies have demonstrated that SAG isolates favour binding to the dermatan sulphate glycosaminoglycan chains conjugated 
Waddingaton et al. Microbiology Discovery 2013,

to decorin and biglycan, along with fibronectin, which are all predominant in soft tissues of PDL and skin. Adherence was lower for the chondroitin sulphate conjugated decorin and biglycan which is predominant in osseous tissues, suggesting a preference for colonisation of soft connective tissues [22]. Numerous streptococcal species have also been shown to bind to heparin sulphate, which are components of cell surface proteoglycans such as syndecan, via microbial surface cell recognition adhesion matrix molecules (MSCRAMMs) [23-26]. These host-microbial interactions lead to the initiation of reciprocated processes whereby factors from eukaryotic cells are able to engage with and change the activity of prokaryotic cells and vice versa. This ability is recognised as a crucial first step in the development of infection, although neither the factors involved in evoking these responses, nor the cellular responses have been investigated in any detail. The aims of this study were therefore to characterise the effect of soluble components from various SAG isolates on PDL cells and endothelial cells in considering their biological activities towards synthesis of new periodontal tissues. Conversely, the effect of the extracellular components synthesised by PDL cells in altering the pathogenic activity of the SAG isolates was also investigated. Further, this study compared the responses of SAG isolates recovered from healthy body sites, regarded as part of the normal commensal microflora, and clinical infections in an attempt to consider factors causing pathogenic induction.

\section{Materials and Methods}

Isolation and culture of periodontal ligament-like cells PDL cells were obtained from $1 \mathrm{~mm}^{2}$ alveolar bone pieces dissected from bone lining the teeth of 28 day-old male Wistar rats. Bone pieces were incubated with $1 \mathrm{mg} / \mathrm{ml}$ collagenase, $4.5 \mathrm{U} / \mathrm{ml}$ elastase (Type IV, Sigma Chemical Co.), $2 \mathrm{~h}, 37^{\circ} \mathrm{C}$. Released cells were decanted from the bone chips, mixed with equal volume of Dulbecco's modified Eagle's medium (DMEM) (Gibco), 10\% fetal bovine serum (FBS), 100 units $/ \mathrm{ml}$ penicillin $\mathrm{G}, 10 \mathrm{mg} / \mathrm{ml}$ streptomycin sulphate, $25 \mathrm{mg} / \mathrm{ml}$ amphotericin B) (Sigma Aldrich) and recovered by centrifugation at $1000 \mathrm{~g}$, $5 \mathrm{~min}$. Cells were seeded at $10^{4} \mathrm{cells} / \mathrm{cm}^{2}$ in T-75 tissue culture flasks and cultured in the above DMEM media, $37^{\circ} \mathrm{C}, 5 \% \mathrm{CO}_{2}$. Cells were utilised at passage 2-4.

\section{Endothelial cell source and culture}

Human endothelial cell line EA.hy926 represents an immortalised cell line generated by fusion of human umbilical vein endothelial cells with the immortalised human lung epithelial carcinoma cell line A549, retaining the signalling characteristics of human umbilical vein endothelial cells [27]. Cells were cultured in MCDB 131 medium (Invitrogen) supplemented with 10\% (v/v) foetal calf serum, $100 \mu \mathrm{M}$ hypoxanthine, $0.4 \mu \mathrm{M}$ aminopterin, 16 $\mu \mathrm{M}$ thymidine (Invitrogen), $100 \mathrm{units} / \mathrm{ml}$ penicillin, and 100 $\mu \mathrm{g} / \mathrm{ml}$ streptomycin.

\section{Bacterial sources and supernatant preparation}

SAG isolates were collected from clinically healthy sites (suffixed with C) and sites of infection. SAG had previously been characterised and designated as S. constellatus (322/95, source dentoalveolar abscess; $34 \mathrm{C}$, source tongue), S. anginosus (43586/96, source high vaginal swab; $43 C$, source tongue) and S. intermedius (127/95, HW13, source dentoalveolar abscess; $30 \mathrm{C}, 11 \mathrm{C}$ source tongue; $84 \mathrm{C}$, source plaque) using a phenotypic identification scheme [28]. Bacteria were anaerobically cultured in $10 \mathrm{ml}$ Brain Heart Infusion (BHI) medium at $37^{\circ} \mathrm{C}$, to an $\mathrm{OD} 550_{\mathrm{nm}}=0.5$. Five $\mathrm{ml}$ of bacterial suspension was added to $45 \mathrm{ml}$ of fresh $\mathrm{BHI}$ and incubated to stationary phase $\left(8 \mathrm{~h} ; \sim 10^{8}\right.$ colony forming units $\left.(\mathrm{cfu}) / \mathrm{ml}\right)$. Bacteria were harvested by centrifugation at $3500 \mathrm{~g}$ for 10 min. Supernatants were passed through a $0.2 \mu \mathrm{m}$ filter and protein concentrations determined using a bicinchoninic acid (BCA) protein assay (Thermo Fisher Scientific Inc, IL, USA).

\section{Influence of bacterial supernatant on PDL and endothelial cell viability}

PDL and EA.hy926 cells were seeded in 24 well plates at $10^{4}$ cells $/ \mathrm{ml}$ and cultured with $1 \mathrm{ml}$ of their respective media, $37^{\circ} \mathrm{C}$, $5 \% \mathrm{CO}_{2}$ for $24 \mathrm{~h}$. Media $(500 \mu \mathrm{l})$ was replaced with fresh media containing bacterial supernatants, to give a final concentration of $10 \mathrm{ng}-500 \mu \mathrm{g}$ protein $/ \mathrm{ml}$ of media (determined by the BCA assay). For uninoculated control cultures, $500 \mu$ l of media was replaced with $500 \mu \mathrm{l}$ of PBS. At 24 and $48 \mathrm{~h}$, cells were washed with phosphate buffered saline (PBS), stained with $0.4 \%$ trypan blue and the percentage of viable (non-stained) cells was immediately determined by microscopic enumeration. Sub-toxic levels, where cell viability was greater than $95 \%$ were determined as $<20 \mathrm{ng} / \mathrm{ml}$ for PDL cells and $<100 \mathrm{ng} / \mathrm{ml}$ for EA.hy 926 cells, for each bacterial isolate. These sub-toxic levels were used in all subsequent analysis to assess effects on host cell biological behaviour.

\section{Influence of bacterial supernatant on PDL and endothelial cell growth}

PDL and EA.hy926 cells were seeded in 24 well plates at $10^{4}$ cells $/ \mathrm{ml}$ in their respective media. After $24 \mathrm{~h}$, media was replaced and cells were cultured with media supplemented with either $0 \mathrm{ng} / \mathrm{ml}$ or $20 \mathrm{ng} / \mathrm{ml}$ (PDL cells) or $0 \mathrm{ng} / \mathrm{ml}$ or 100 $\mathrm{ng} / \mathrm{ml}$ (EA.hy926 cells) of the respective SAG supernatants (day 0). Cell growth was determined using an MTT assay (R\&D Systems Europe, Oxon, UK) over 0-5 days, as per manufacturer's instructions. Triplicate assays were performed for each supernatant on three separate occasions.

\section{Influence of bacterial supernatant on collagen synthesis by PDL cells}

PDL cells were seeded on to round glass coverslips in 6-well culture dishes at $10^{4}$ cells $/ \mathrm{cm}^{2}$, and cultured for $24 \mathrm{~h}$, after which media was replaced with media supplemented with $0 \mathrm{ng} / \mathrm{ml}$ or $20 \mathrm{ng} / \mathrm{ml}$ of SAG supernatants (day 0 ) which was 
renewed every $24 \mathrm{~h}$. At 5-13 days, cells were fixed in $2 \%$ formaldehyde for $30 \mathrm{~min}$ and then washed in PBS. Cells were blocked with 1\% normal horse serum in PBS (Sigma Aldrich), for $10 \mathrm{~min}$ and then incubated with mouse monoclonal anticollagen type I (Sigma Aldrich; 1:2,000 dilution in 0.5\% horse serum, PBS) for $1 \mathrm{~h}$. Immunoreactivity was detected with rabbit anti-mouse IgG FITC conjugate secondary antibody (Sigma Aldrich; 1:1000) at for $30 \mathrm{~min}$, and viewed under a fluorescent microscope ( $\times 40$ objective).

\section{Influence of bacterial supernatant on endothelial cell migration}

A migration assay was performed using endothelial cells cultured as spheroids [17]. Briefly, single uniform spheroids were prepared from 1000 EA.hy 926 cells per well of a 96-well round bottom hydrophobic plate, suspended in Waymaouth MAB $87 / 3$ medium supplemented with $5 \%$ heat-inactivated foetal calf serum and $30 \%$ methyl cellulose (Sigma Aldrich) for $48 \mathrm{~h}, 37^{\circ} \mathrm{C}, 5 \% \mathrm{CO}_{2}$. Spheroids were transferred, one per well of a flat bottomed 96 -well hydrophilic plate, pre-coated with $0.125 \mathrm{mg}$ of type 1 collagen (extracted from rat tail [17]) and cultured in $100 \mu \mathrm{l}$ Waymouth medium supplemented with $0.5 \%$ heat-inactivated foetal calf serum, and $0 \mathrm{ng} / \mathrm{ml}$ or $100 \mathrm{ng} / \mathrm{ml}$ of SAG supernatant, $37^{\circ} \mathrm{C}, 5 \% \mathrm{CO}_{2}$ for $0-72 \mathrm{~h}$. Cells migrating away from the spheroid bodies, eventually form a ring of cells resembling sprout-like extensions associated with angiogenesis. For spheroids located close to the centre of the well, cell migration was recorded as digital images after $6 \mathrm{~h}$ and then every $24 \mathrm{~h}$ over 3 days. Spheroid width was measured using Adobe Photoshop (Adobe Systems Incorporated) and the ruler tool, and means with standard deviations calculated for each time-point from a minimum of 12 wells for each supernatant.

\section{Influence of bacterial supernatant on mRNA expression of decorin}

PDL cells were seeded at $10^{4}$ cells $/ \mathrm{cm}^{2}$ in 6-well plates for $24 \mathrm{~h}$, after which the culture medium was supplemented with or without SAG supernatant, and changed every 24 h. At days 10 and 13, cells were washed with PBS and the total RNA extracted using a Qiagen RNeasy Mini kit (Qiagen Ltd, UK). cDNA was synthesised from $500 \mathrm{ng}$ of total RNA, after which PCRs were performed using primer sequences to decorin (sense 5'-CAATAGCATCACCGTTGTGG-3', anti-sense 5'-CCGGACAGGGTTGCTATAAA-3') and glyceraldehyde-3-phosphate dehydrogenase (GAPDH) (sense 5'-TCCCTCAAGATTGTCAGCAA-3', anti-sense 5'-AGATCCACAA CGGATACATT-3'). PCR cycling parameters used were $94^{\circ} \mathrm{C}, 3 \mathrm{~min}, 35 \mathrm{cycles}$ at $94^{\circ} \mathrm{C}, 1 \mathrm{~min}$ $58^{\circ} \mathrm{C}, 1 \mathrm{~min}$ and $72^{\circ} \mathrm{C}, 5 \mathrm{~min}$. RT-PCR products were examined on $2 \%$ agarose gels containing ethidium bromide and viewed under UV light, using a BioRad image analysis system (BioRad Laboratories Ltd.). Band intensities were determined by normalisation to GAPDH using the BioRad Quantity One calibration programme, to provide a descriptive analysis of temporal trends and gross changes in the expression patterns Experiments were performed on three separate occasions. The amplification of GAPDH was also performed for 15,25 , 35 and 45 cycles, using the same starting concentrations of $500 \mathrm{ng}$ total RNA, $1 \mathrm{mM}$ dNTPs, $25 \mathrm{pg} / \mu \mathrm{l}$ random hexamers and $4 \mathrm{U} / \mathrm{\mu l}$ reverse transcriptase. RT-PCR products were readily seen following 35 cycles, which increased in intensity after 45 cycles, confirming that the reaction had been stopped in the exponential phase and had not reached the plateau phase (Figure 2).

Influence of bacterial supernatant on decorin synthesis PDL cells were seeded at $10^{4}$ cells $/ \mathrm{cm}^{2}$ with or without SAG supernatant as described above. Media was collected at days 10 and 13 and dialysed against double distilled water. Protein concentrations were determined using the BCA assay according to the manufacturer's instructions and then adjusted to $20 \mathrm{mg} /$ $\mathrm{ml}$. Samples $(20 \mu \mathrm{l}$ containing $400 \mu \mathrm{g}$ protein per well) were mixed with an equal volume of $0.2 \mathrm{M}$ tris- $\mathrm{HCl}$ buffer, $0.06 \mathrm{M}$ sodium acetate, $\mathrm{pH} 8$ containing 2 units $/ \mathrm{ml}$ chondroitinase $A B C$ (protease free, Seikagku Corporation, Tokyo) and incubated at $37^{\circ} \mathrm{C}$ for $1-2 \mathrm{~h}$. The resultant core proteins were then mixed with an equal volume of $0.125 \mathrm{M} \mathrm{Tris-} \mathrm{HCl}, \mathrm{pH} 6.8,20 \%$ glycerol, $4 \%$ SDS, $10 \%$ 2- $\beta$-mercaptoethanol, $0.004 \%$ bromophenol blue and examined by SDS-PAGE using a Phastsystem (GE Healthcare) followed by Western blot analysis for detection of immuno-reactivity with antibodies rabbit anti-mouse decorin (LF-113) as previously described by [29].

\section{Influence of PDL derived extracellular matrix on bacterial protein synthesis}

PDL cells were cultured in DMEM culture media (as above) at $37^{\circ} \mathrm{C}, 5 \% \mathrm{CO}_{2}$, to $95 \%$ confluency. Media was then changed for media with $0.2 \%$ FBS and cultured for a further $48 \mathrm{~h}$. Collected media was exhaustively dialysed against double distilled water, lyophilised and extracellular matrix (ECM) protein concentration determined using the BCA assay (Thermo, Fisher Scientific Inc, IL, USA). SAG bacteria (duplicate samples for each isolate) were inoculated into $\mathrm{BHI}$ broth to give $\mathrm{OD}_{550 \mathrm{~nm}}=0.2$ and cultured anaerobically for $18 \mathrm{~h}$. One $\mathrm{ml}$ of BHI was transferred to $9 \mathrm{ml}$ of fresh BHI broth and cultured until mid-log phase (approximately $4 \mathrm{~h}$ ). Bacteria were then cultured for a further $4 \mathrm{~h}$, anaerobically, with or without $250 \mu \mathrm{g} / \mathrm{ml}$ of protein collected from the PDL cells. This higher concentration of ECM proteins (compared with the 20 or $100 \mathrm{ng} / \mathrm{ml}$ concentrations of bacterial supernatants utilised in the above assays) was selected to reflect the higher concentration of matrix components compared to bacterial cells in vivo and did not affect the growth of the bacteria in culture. One-ml aliquots of bacterial suspensions were collected for subsequent analysis.

Bacterial aliquots were lyophilised and $10 \mu \mathrm{g}$ of each bacterial suspension was dissolved in sample buffer $(0.062 \mathrm{M}$ Tris- $\mathrm{HCl}$, $\mathrm{pH} 6.8,10 \%$ glycerol, $2 \%$ SDS, 5\% 2- $\beta$-mercapthoethanol, 


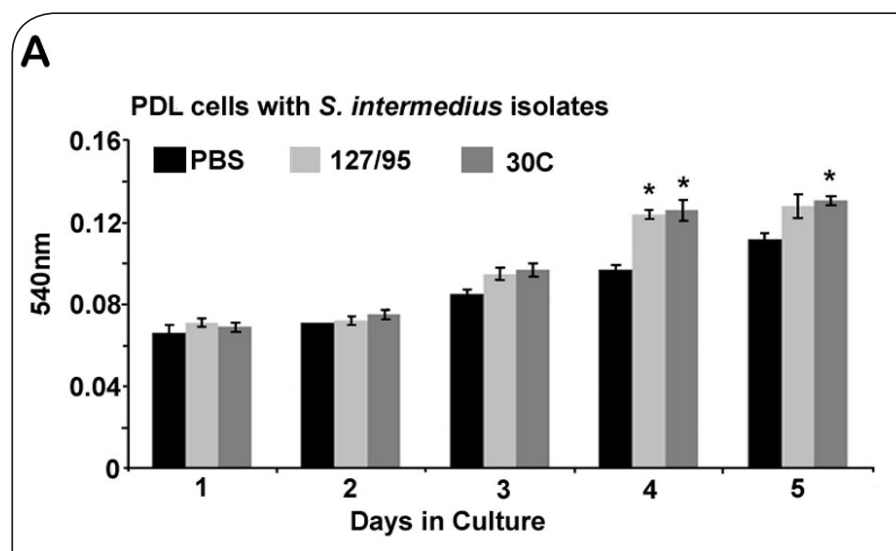

B
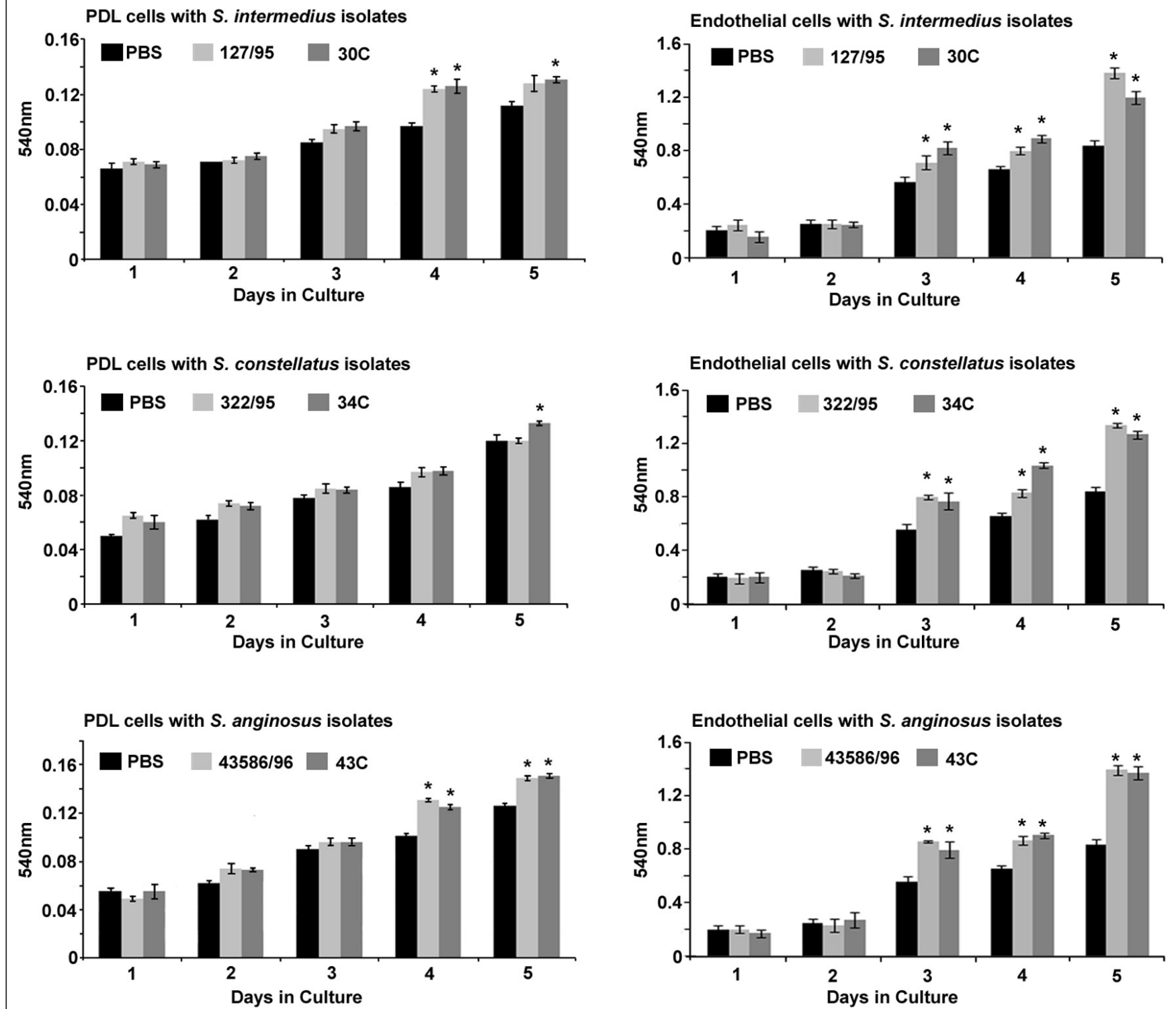

Figure 1. The influence of non-lethal concentrations of supernatant proteins derived from SAG bacterial cultures on (A) PDL and (B) endothelial cell numbers over 5 days of culture. Cells were cultured for $24 \mathrm{~h}$ following reseeding at $10^{4} \mathrm{cells} / \mathrm{cm}^{2} \mathrm{before}$ supplementation of media with either 0 or $20 \mathrm{ng} / \mathrm{ml}$ (PDL cells) or 0 or $100 \mathrm{ng} / \mathrm{ml}$ (endothelial cells) of the SAG supernatants. Cell growth was determined using the MTT assay with cell numbers proportional to absorbance at $540 \mathrm{~nm} .{ }^{*} \mathrm{p}<0.05$ indicates statistically significant difference when compared to the non supplemented control at the same day of culture.

$0.002 \%$ bromophenol blue) and separated on $4-15 \%$ gradient SDS-PAGE gels using the Phast System (GE Healthcare) as previously described [29]. Gels were stained with $0.05 \%$ Coomassie brilliant blue, 50\% methanol, 10\% acetic acid for $1 \mathrm{~h}$ and destained with 50\% methanol, 10\% acetic acid.

\section{Influence of PDL derived extracellular matrix on bacterial enzyme activity}

One $\mathrm{ml}$ of bacterial suspension, cultured with or without $250 \mu \mathrm{g} / \mathrm{ml}$ ECM proteins, was diluted with distilled water to equate to a turbidity of 5-6 on the McFarland Scale and analysed using API ZYM (bioMerieux, Marcy-I'Etoile, France) for the semi-quantitative micro-identification of enzymatic activities. Based on colour development and comparing to manufacturer's reading table, activity was graded from 0-5. Due to subjectivity, two individual readers were used.

Chondroitinase and hyaluronidase activity was measured using a spectroscopic assay monitoring the formation of unsaturated bond resulting from the digestion of chondroitin 4-sulphate and hyaluronan [30]. Duplicate $1 \mathrm{ml}$ bacterial suspension samples, taken at mid-log stage were added to $4 \mathrm{ml} \mathrm{BHI}$ media containing $400 \mu \mathrm{g} / \mathrm{ml}$ of either hyaluronan 
or chondroitin 4-sulphate (Sigma Aldrich), with or without supplementation of $250 \mu \mathrm{g} / \mathrm{ml} \mathrm{ECM} \mathrm{proteins} \mathrm{and} \mathrm{incubated}$ anaerobically for 7 days. Bacterial samples were centrifuged at $3000 \mathrm{~g}, 10 \mathrm{~min}, 20 \mu \mathrm{l}$ of supernatant was mixed with $4 \mathrm{ml}$ of distilled water and the absorbance $232_{\mathrm{nm}}$ recorded. Noninoculated broth served as a negative control for background subtraction.

Influence of PDL derived extracellular matrix on intermedilysin (ILY) production by S. intermedius Total RNA was extracted from $1 \mathrm{ml}$ samples of $S$. intermedius isolates using a Qiagen RNeasy Mini kit (Qiagen Ltd, West Sussex, UK) and CDNA was generated. PCR of the ILY gene was performed according to previous methods [31] using ILY forward primer (5'-AACACCTACCAAACCAAAAGCAGC-3'), ILY reverse primer (5'-ACTGTGGATGAAGGGTTGTTCCCC- $3^{\prime}$ ), $1.5 \mathrm{mM} \mathrm{MgCl}_{2}$ and the cycling parameters of $95^{\circ} \mathrm{C}, 5$ min, followed by 30 cycles at $95^{\circ} \mathrm{C}, 1 \mathrm{~min}, 55^{\circ} \mathrm{C}$ for $1 \mathrm{~min}$, followed by a final $72^{\circ} \mathrm{C}, 2 \mathrm{~min}$ extension step. To quantify ILY expression, the $16 \mathrm{~S}$ rRNA of $S$. intermedius isolates was also amplified from bacterial CDNA using the primer pair 27F (5'-GTGCTGCAGAGAGTTTGATCCTGGCTCAG-3') and 1492R (5'-CACGGATCCTACGGGTACCTTGTTACGACTT-3'). PCR was performed for $1 \mathrm{cycle}$ of $94^{\circ} \mathrm{C}, 6 \mathrm{~min}, 65^{\circ} \mathrm{C}, 1 \mathrm{~min}, 72^{\circ} \mathrm{C}, 2 \mathrm{~min}$ followed by 11 cycles where denaturation was performed for $1 \mathrm{~min}$ and the annealing temperature was decreased by $2^{\circ} \mathrm{C}$ each cycle, after which 25 cycles were carried out under the same conditions. The final cycle, extension was performed for $12 \mathrm{~min}$.

\section{Results}

Influence of SAG supernatants on PDL cell behaviour Culture of PDL cells in the presence of supernatants derived from SAG isolates appeared to result in stimulation in cell expansion (Figure 1A). For cells exposed to supernatants derived from $S$. intermedius and $S$. anginosus, a significantly higher number of cells were observed by day $4(p<0.05)$ and this was consistent for isolates derived from clinically healthy and pathologically infected sites. For PDL cells exposed to supernatant derived from S. constellatus, cell expansion appeared to be greater compared to the non supplemented control, but this was observed to be statistically significant for cells exposed to S. constellatus 34C (isolate from clinically healthy site) at day 5 . All isolates appeared to reduce the ability of the PDL cells to synthesise matrix components (Figure 2). Decorin mRNA expression appeared to be affected with all isolates, demonstrating a trend towards an approximate $20 \%$ to $43 \%$ reduction in levels compared to the non supplemented control (Figure 2A). These results were supported by Western blot analysis which demonstrated a very large reduction in protein levels of decorin in the media collected from PDL cells grown in the presence of SAG isolates compared to the non supplemented control (Figure 2B). Also observed was an increase in low molecular weight decorin degradation products in the molecular weight range 20-12kDa. Immunofluorescence labelling of cell cultures for type 1 collagen demonstrated reduced levels at day 7 and a complete absence at days 10 and 13 following exposure to SAG supernatants (Figure 2C). These observations for collagen and decorin synthesis were consistent for all isolates studied.

\section{Influence of SAG supernatants on endothelial cell behaviour}

Exposure of endothelial cells to SAG supernatants stimulated cell expansion (Figure 1B), with significantly greater cell numbers observed by day 3 in supplemented cultures compared with non supplemented cultures $(p<0.05$ for all comparison). No significant differences were observed in comparing effects of supernatants for isolates obtained from either clinically healthy or pathogenic sites (p.0.05). The effect of SAG soluble components on the migration of endothelial cells was also examined by measuring radial outward migration from a pre-formed spheroid of endothelial cells (Figure 3) which was intended to mimic endothelial migration during sprout formation from pre-existing vessels [17]. By 6 $h$, in the absence of SAG supernatants, cells demonstrated a statistically significant higher migration ability (2- to 3-fold higher) compared to cells cultured in the presence of the SAG supernatants $(p<0.05)$. For $S$. intermedius $127 / 95$, S. constellatus $322 / 95$ and S. anginosus $43586 / 96$ and $43 C$, the rate of migration of the cells over the subsequent 6-72 $\mathrm{h}$ appeared similar and cells maintained a $30-60 \%$ reduction in the overall distance of cell migration compared with migratory distances achieved by cells cultured in the absence of bacterial supernatant ( $p<0.05$ for all comparisons). Migration rates for cells in the presence of supernatant from isolates $30 \mathrm{C}$ (S. intermedius) and 34C (S. constellatus) appeared slightly greater compared with other isolate supernatants, but this was shown not to be significant. The distance of migration of cells in the presence of these bacterial supernatants was also significantly decreased compared with non supplemented controls.

Protein expression by SAG in the presence and absence of PDL extracellular matrix

SDS PAGE analysis of the bacterial supernatants derived from the SAG isolates revealed a series of faint bands ranging in molecular weight from $188-22 \mathrm{kDa}$ (Figure 4). In the presence of ECM proteins synthesised by PDL cells, a strongly staining band was apparent for all isolates, with variable molecular weight ranging between 59 and $69 \mathrm{kDa}$. In addition, for each isolate, a different profile of lower molecular weight staining protein bands $(55-49 \mathrm{kDa})$. For all SAG, a protein band with molecular weight of approximately $72 \mathrm{kDa}$ was also observed in the presence of the ECM components, which was absent in SAG with no ECM. Separation of the bacterial culture medium and the ECM components alone failed to produce any distinguishable bands, indicating that all bands observed 
Waddingaton et al. Microbiology Discovery 2013,

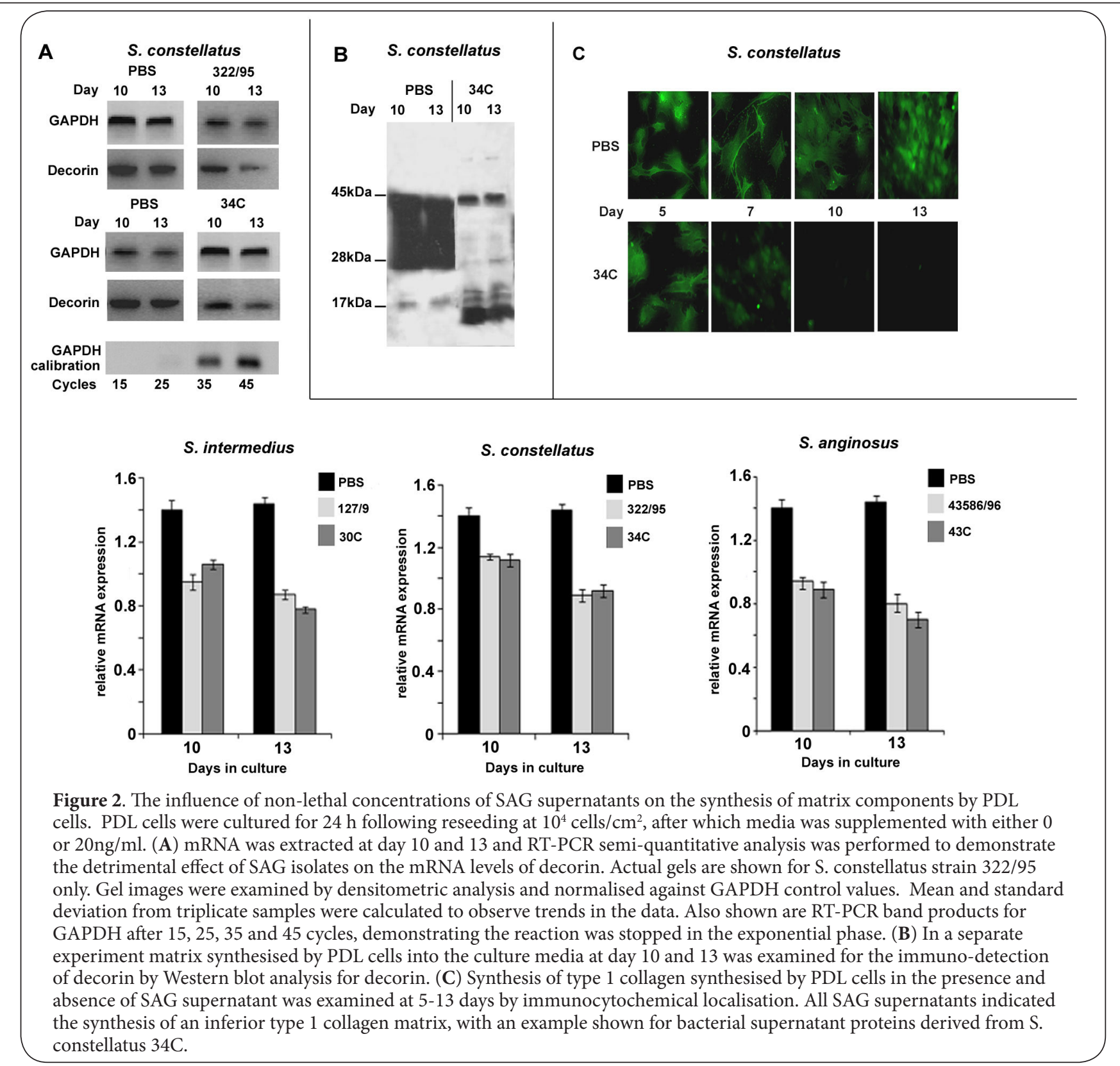

in the presence of the SAG were bacterially derived. There was no similarity seen in the profile of protein bands on comparing isolates from clinically healthy and pathogenic sites or in comparing species within the SAG group.

Assessment of the enzyme profile produced by the SAG isolates is shown in Table 1. The three species within the SAG differed in their ability to produce an array of enzymes. There was negligible activity for esterase and no activity of esterase lipase, lipase or $\beta$-glucouronidase for any isolate (data not shown). Of note, the API ZYM assay demonstrated an increase in alkaline phosphatase, phosphohydrolase and a-glucuronidase, except where levels were already graded as relatively high (scoring 4 or 5 ). Trypsin-like protease activity increased in the presence of ECM components for commensal isolates of S. constellatus and S. intermedius, to levels similar to those present with $S$. constellatus and S. intermedius isolated from pathogenic sites. Trypsin-like protease levels were low for pathogenic isolates of $S$. anginosus and absent from commensal isolates. Activity of the glycosaminoglycan depolymerising enzymes chondroitinase and hyaluronidase was detectable in S. constellatus and S. intermedius isolates and was not seen to increase in the presence of the ECM proteins.

Detected only in the $S$. intermedius isolates, mRNA expression of ILY, normalised against 16SrRNA levels, was assessed in several isolates assigned to this stain (Figure 5). For isolates collected from clinically healthy sites, ILY levels 


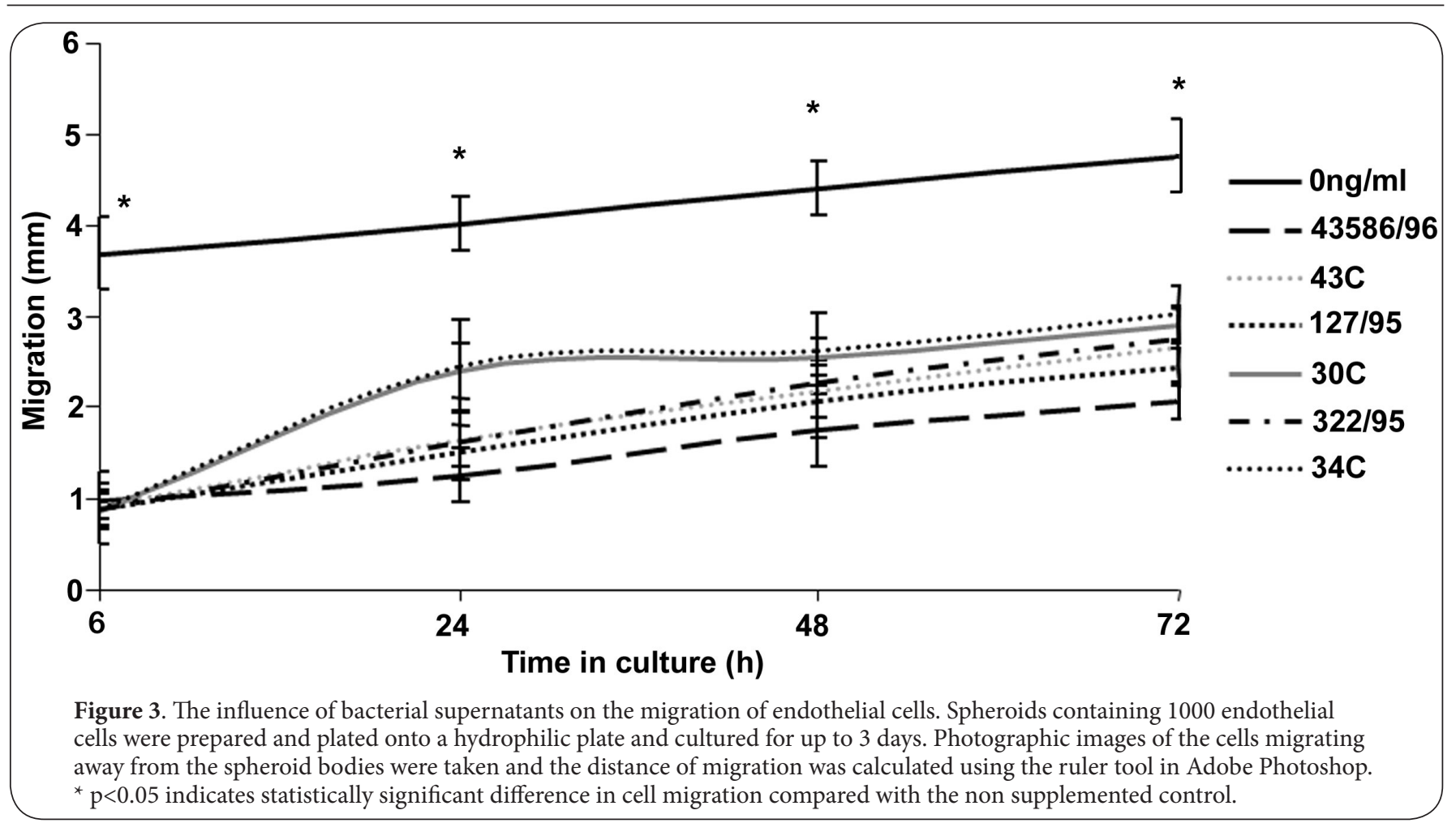

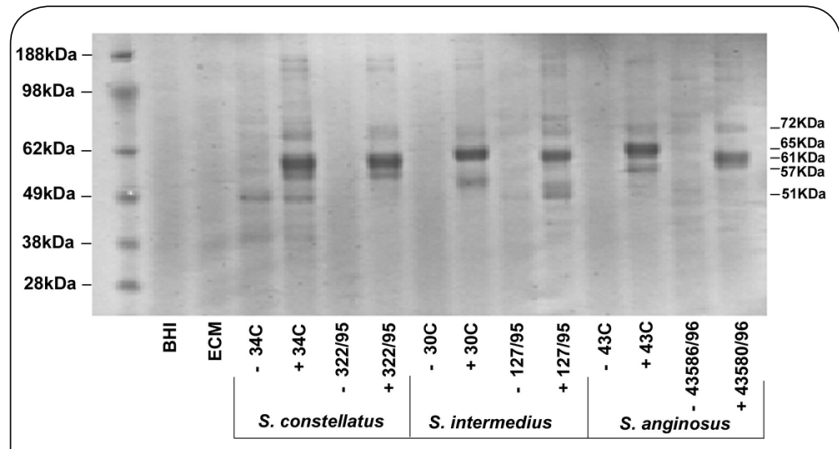

Figure 4. Molecular weight profile of proteins produced into the culture supernatant of SAG isolates in the absence and presence of ECM proteins synthesised by PDL cells. ECM was prepared as conditioned media following the culture of confluent PDL cells for $48 \mathrm{~h}$. SAG were grown from the mid-log phase in broth supplemented in the ECM proteins for $4 \mathrm{~h}$ and the culture supernatant was examined by SDS PAGE. Also shown is a separation of the brain heart infusion broth alone (BHI) and the ECM proteins in the culture broth in the absence of bacteria (ECM).

were observed to increase in the presence of ECM proteins to levels similar to those identified in strains collected from pathogenic sites. There was no further increase in ILY for these pathogenic strains in the presence of ECM proteins.

\section{Discussion}

This study has demonstrated that protein components released from SAG isolates were all similarly capable of disrupting the proliferation of and matrix synthesis by PDL cells, and

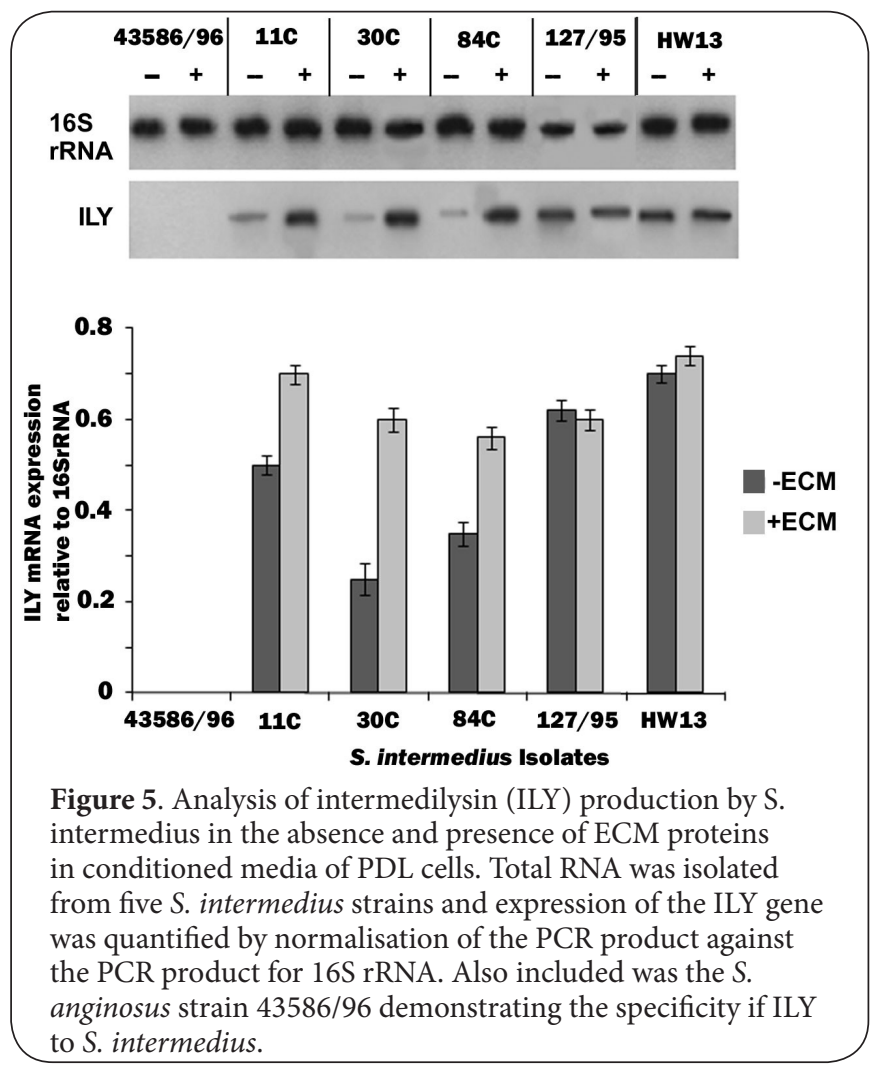

the proliferation and migration of endothelial cells. This would have an obvious impact on tissue repair processes required in the maintenance of the structural integrity of 
Waddingaton et al. Microbiology Discovery 2013,

Table 1. Enzyme activity identified in SAG isolates in the presence and absence of extracellular matrix (ECM) proteins synthesised by PDL cells, as determined by the API ZYM and glycosaminoglycan depolymerise assays. $\boldsymbol{\Delta}$ indicates an increase in activity of greater than 2 scores, as judged by the API ZYM assay, compared to the control in the absence of ECM proteins.

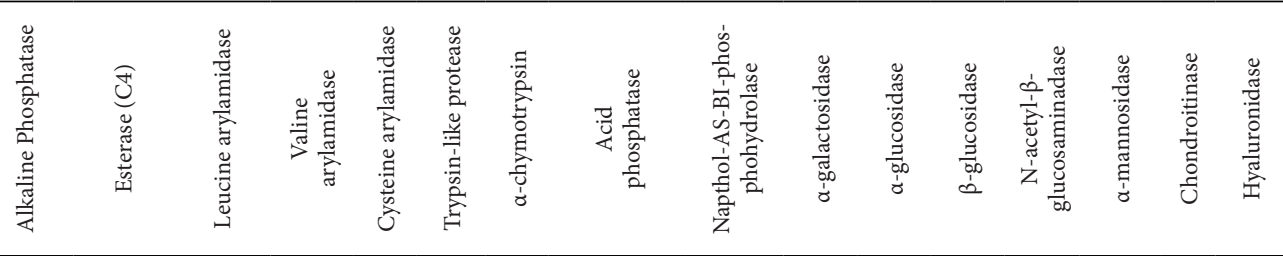

\begin{tabular}{|c|c|c|c|c|c|c|c|c|c|c|c|c|c|c|c|c|c|}
\hline ECM only & & - & - & - & - & - & - & - & - & - & - & - & - & - & - & - & - \\
\hline \multirow{3}{*}{$\begin{array}{l}322 / 95 \\
\text { (S. constellatus) }\end{array}$} & No ECM & 4 & 1 & 5 & 2 & 3 & 2 & 1 & 5 & 3 & - & 2 & 2 & - & - & + & + \\
\hline & & & & & & & & $\Delta$ & & $\Delta$ & & $\Delta$ & & & & & \\
\hline & $+\mathrm{ECM}$ & 4 & 1 & 5 & 2 & 2 & 2 & 3 & 5 & 5 & - & 4 & 3 & - & - & + & + \\
\hline \multirow{3}{*}{$\begin{array}{l}34 \mathrm{C} \\
\text { (S. constellatus) }\end{array}$} & No ECM & 5 & - & 5 & 3 & 2 & 0 & 3 & 5 & 2 & - & 2 & 4 & - & - & + & + \\
\hline & & & & & & & $\Delta$ & & & $\Delta$ & & $\Delta$ & & & & & \\
\hline & $+\mathrm{ECM}$ & 5 & - & 5 & 3 & 3 & 3 & 3 & 5 & 5 & - & 4 & 5 & - & - & + & + \\
\hline \multirow{3}{*}{$\begin{array}{l}\text { 127/95(S. inter- } \\
\text { medius) }\end{array}$} & No ECM & 5 & - & 5 & 3 & 3 & 2 & 3 & 5 & 3 & - & 2 & 2 & 2 & 2 & + & + \\
\hline & & & & & & & & & & & & $\Delta$ & & $\Delta$ & $\Delta$ & & \\
\hline & $+\mathrm{ECM}$ & 5 & - & 5 & 3 & 4 & 2 & 3 & 5 & 4 & - & 4 & 3 & 5 & 4 & + & + \\
\hline \multirow{2}{*}{$\begin{array}{l}\text { 30C } \\
\text { (S. intermedius) }\end{array}$} & No ECM & 1 & - & 2 & 2 & 1 & 0 & 0 & 2 & 2 & - & 0 & 1 & 1 & 3 & + & + \\
\hline & & $\Delta$ & & $\Delta$ & & & $\Delta$ & $\Delta$ & $\Delta$ & $\Delta$ & & $\Delta$ & $\Delta$ & $\Delta$ & & & \\
\hline \multirow{3}{*}{$\begin{array}{l}43586 / 96 \\
\text { (S. anginosus) }\end{array}$} & No ECM & 3 & - & 5 & 4 & 4 & 1 & 2 & 5 & 2 & 1 & 1 & 1 & - & 0 & - & - \\
\hline & & $\Delta$ & & & & & & $\Delta$ & & $\Delta$ & $\Delta$ & $\Delta$ & $\Delta$ & & $\Delta$ & & \\
\hline & $+\mathrm{ECM}$ & 5 & - & 5 & 4 & 4 & 2 & 4 & 4 & 4 & 3 & 4 & 3 & - & 3 & - & - \\
\hline \multirow{3}{*}{ 43C (S. anginosus $)$} & No ECM & 1 & - & 4 & - & - & - & 1 & 1 & 3 & - & 2 & - & 0 & - & - & - \\
\hline & & $\Delta$ & & & & & & & & & & $\Delta$ & & $\Delta$ & & & \\
\hline & $+\mathrm{ECM}$ & 3 & - & 4 & - & - & - & - & 2 & 4 & 1 & 4 & - & 3 & - & - & - \\
\hline
\end{tabular}

PDL and represent the first crucial steps in the establishment of infection and tissue destruction. In addition, this study also demonstrated that extracellular components synthesised by PDL cells were capable of increasing the hydrolytic enzyme activity of SAG, thus providing the potential to exacerbate tissue damage. Significantly, the results indicate similar responses for S. intermedius, S. constellatus and S. anginosus isolates, irrespective of whether they were commensal isolates, collected from healthy body sites or pathogenic isolates from clinical infection.

The cell population examined in this study would be heterogeneous in nature, but would contain a high proportion of mesenchymal progenitor cells capable of proliferation and subsequent differentiation into collagen synthesising cells. The results of this study have shown that soluble components released by SAG isolates at concentrations as low as $20 \mathrm{ng} / \mathrm{ml}$ increased the active proliferation of the PDL progenitor cell population. Our results demonstrated that soluble components of SAG isolates severely disrupted collagen levels within the extracellular matrix and organisation of the collagen fibrils, with a near absence of collagen in cultures after 10 days. The latter observation may be due to the hydrolytic enzyme activity in the SAG supernatant, which was identified in this study (API ZYM results demonstrate enzyme activity in the absence of ECM components synthesised by the PDL cells) or by SAG components stimulating matrix degradation activity by the PDL cells [14]. However, this study also demonstrated that in the presence of SAG soluble components, the mRNA expression and protein synthesis of decorin was severely reduced, which may be additionally reduced due to host degradative activity or bacterial hydrolytic enzyme activity. In considering decorin's role in collagen fibrillogenesis $[12,13]$, the reduction in levels of a functional decorin would be expected to lead to an inferior collagen matrix, making it highly susceptible to hydrolytic enzymes released by the SAG isolates.

Decorin has also been ascribed both direct and indirect roles in regulating cell signalling and proliferation. Decorin is proposed to sequester growth factors to the matrix such as TGF $\beta$ [32], Wnt-l-induced secreted protein I (WISP-I) [33], TNFa [34] and BMP2 [35], protecting it from proteolysis but at the same time regulating its release to the target cell, indirectly regulating its activity. Of note, TGF $\beta 1$ has been shown to increase proliferation and chemotaxis of PDL cells [36-38], thus the reduction in decorin available to bind TGF $\beta$ may indirectly account for the increased cell growth seen 
in this study. Likewise the reduction of decorin may release free TNFa propagating its pro-inflammatory cellular responses. Decorin has also been shown to directly signal to PDL cells $[14]$ and squamous carcinoma cells $[39,40]$ arresting cell proliferation. Although the signal transduction pathway has not been identified in PDL cells [14], the reduced synthesis of decorin in the presence of SAG components may further account for the increased proliferation of these mesenchymal progenitor cells.

Within this study, soluble components from all SAG isolates stimulated endothelial cell expansion, however, migration of endothelial cells across a collagen matrix was reduced, suggesting that within a clinical SAG infection site angiogenesis would be impaired. Neither mRNA expression nor protein synthesis of decorin were detected for the endothelial cells in monolayer culture (results not shown). This concurs with previous data which indicate that decorin is expressed by sprouting endothelial cells contributing to angiogenesis during inflammatory conditions, but not quiescent endothelial cells [41]. Indeed, in vitro studies have indicated that within a collagen matrix, decorin activates the insulin-like growth factor-I receptor and interacts with the a $2 \beta 1$ integrin leading to reorganisation of the cytoskeleton and focal adhesion to promotes endothelial adhesion and motility [17]. The reduction in decorin synthesis by PDL like cells, observed in our study, could therefore also impact on angiogenesis within the periodontal tissue at sites of SAG infections. These would be additional to the direct effects of soluble components released by SAG on the endothelial cell motility.

SDS PAGE demonstrated that the profile of soluble components released by the various SAG isolates was variable, with some potential for common components, but at differing concentrations. In particular, there were large variations in the protein profiles of isolates designated commensal, derived from clinically healthy, or pathogenic, from infected sites, yet identified as the same species. All SAG isolates were able to influence the biological activity of both PDL cells and endothelial cells towards phenotypes which do not favour tissue repair. In considering the reciprocal process, the results of the present study also demonstrated that components within the ECM were able to increase the production of specific hydrolytic enzymes produced by the SAG isolates. In particular, ECM components were shown to increase napthol-AS-B1-phosphohydrolase activity, which along with alkaline phosphatase, esterase lipase, lipase, leucine arylamidase and acid phosphatase, has been proposed as a bacterial 'housekeeping' enzyme required for survival [42]. Streptococcus constellatus and S. intermedius isolates produced enzymes which are capable of modifying the carbohydrate moieties of various proteoglycans or glycoproteins which are utilised by the bacteria as a carbon source. These included chondroitinase and hyaluronidase which were at a relatively low level and did not increase in the presence of the ECM components. Enzymes such as a-galactosidase, $\beta$-glucosidase,
$\mathrm{N}$-acetyl- $\beta$-glucuronidase and $\alpha$-mannose demonstrated a varied and often low expression across the SAG isolates. However, in the presence of ECM components a 2 to 4 fold rise in the levels of a-glucuronidase was seen for all isolates. For proteolytic enzymes, trypsin-like protease was observed to rise for commensal isolates of S. constellatus and S. intermedius, but levels in the S. anginosus isolates were relatively low. The ECM synthesised by PDL cells contains a diverse array of protein or glycyoconjugates and it has not been possible within this study to identify if specific proteins are responsible for triggering the bacterial expression of the hydrolytic enzymes. This response may equally be unspecific, with bacteria responding to a changing protein or carbohydrate nutrient supply. For S. intermedius isolates, ECM components induced higher levels of ILY, whilst high levels of ILY were apparent in pathogenic strains before exposure to ECM components. ILY is a toxin produced only in S. intermedius and is proposed to interfere with phagocytosis of PMNs and macrophages and, in conjunction with cholesterol, appears to be cytotoxic to these immune cells [43]. Although produced by $S$. intermedius isolates in this study, ILY in the SAG supernatant at the subtoxic concentrations utilised, was probably of insufficient level to be cytotoxic to either PDL cells or endothelial cells, as evidenced by an increase in cell proliferation in the presence of the SAG soluble components. However, it has previously been observed that ILY is essential for $S$. intermedius invasion of human hepatoma HepG2 cells, and that secretion of ILY within host cells is essential for subsequent host cell death [44].

Collectively, the results of this study would suggest that the ECM of PDL plays a prominent role in the establishment and propagation of SAG infection. Our previous studies have demonstrated that these SAG isolates favour binding to the dermatan sulphate conjugated decorin and biglycan and fibronectin, which are all predominant in soft tissues of PDL [22], lending these tissues in particular to bacterial biofilm formation. Whilst this study focussed on periodontal ligament, similar components are present in other soft connective tissues of the body and thus the ECM of these tissues could equally play a prominent role in the establishment of lung, brain and liver abscesses. Soluble components from the SAG isolates appeared to produce a deleterious effect on the biological activity of PDL cells and endothelial cells regardless of whether the SAG were designate as commensal or pathogenic bacteria, possibly suggesting that the ECM components drive the development of a pathogenic phenotype within the SAG. The ECM components have the potential to increase hydrolytic enzyme factors with a consequential influence on the biological activity of the host mesenchymal and immune cells. Whilst not leading to direct gross tissue destruction, degradation of carbohydrate moieties on glycoconjugates such a fibronectin, may lend them susceptible to proteolytic degradation, by either bacterial or mammalian enzymes. The bacterial expression of these enzymes presents the potential for altering the glycosaminoglycan chains of cell membrane 
Waddingaton et al. Microbiology Discovery 2013,

heparin sulphate proteoglycans, the structure of which appears to be important in fulfilling a signalling role $[45,46]$. Of further consideration, research in the literature already suggests that binding cell surface heparin sulphate proteoglycans with various microbial surface cell recognition adhesion matrix molecules (MSCRAMMs) released from the bacterial surface may stimulate intracellular signalling, influencing host cell survival, promotion of antimicrobial peptide synthesis and the initiation of the inflammatory response $[26,47-49]$. It is therefore apparent that whilst this study has elucidated a novel mechanism by which SAG change cellular behaviour via changes in the expression of decorin, this only represents part of the pathological mechanism, which remains on the whole unclear, probably because it is multifactorial in nature.

\section{Competing interests}

The Authors declare that they have no competing interests.

\section{Acknowledgement}

J Landrygan-Bakri was supported by Wales Office for

Research and Development for Health and Social Care in carrying out this study. Antibodies used in this study were a generous gift of L. Fisher, NICDR, NIH, USA.

Publication history

Received: 15-Jan-2013 Revised: 01-Feb-2013

Accepted: 22-Feb-2013 Published: 22-Mar-2013

\section{References}

1. Lewis MA, MacFarlane TW and McGowan DA: Quantitative bacteriology of acute dento-alveolar abscesses. J Med Microbiol 1986, 21:101-4. | Article | PubMed

2. Whiley RA, Beighton D, Winstanley TG, Fraser HY and Hardie JM: Streptococcus intermedius, Streptococcus constellatus, and Streptococcus anginosus (the Streptococcus milleri group): association with different body sites and clinical infections. J Clin Microbiol 1992, 30:243-4. | Article | PubMed Abstract | PubMed Full Text

3. Jacobs JA, Tjhie JH, Smeets MG, Schot CS and Schouls LM: Genotyping by amplified fragment length polymorphism analysis reveals persistence and recurrence of infection with Streptococcus anginosus group organisms. J Clin Microbiol 2003, 41:2862-6. | Article | PubMed Abstract I PubMed Full Text

4. Ledezma-Rasillo G, Flores-Reyes H, Gonzalez-Amaro AM, GarrochoRangel A, Ruiz-Rodriguez Mdel S and Pozos-Guillen AJ: Identification of cultivable microorganisms from primary teeth with necrotic pulps. J Clin Pediatr Dent 2010, 34:329-33. | Article | PubMed

5. Okayama H, Nagata E, Ito HO, Oho T and Inoue M: Experimental abscess formation caused by human dental plaque. Microbiol Immunol 2005, 49:399-405. | PubMed

6. Wong CA, Donald F and Macfarlane JT: Streptococcus milleri pulmonary disease: a review and clinical description of 25 patients. Thorax 1995, 50:1093-6. | Article | PubMed Abstract | PubMed Full Text

7. Shinzato $T$ and Saito A: A mechanism of pathogenicity of "Streptococcus milleri group" in pulmonary infection: synergy with an anaerobe. $J$ Med Microbiol 1994, 40:118-23. | Article | PubMed

8. Nagashima $\mathrm{H}$, Takao $\mathrm{A}$ and Maeda $\mathrm{N}$ : Abscess forming ability of streptococcus milleri group: synergistic effect with Fusobacterium nucleatum. Microbiol Immunol 1999, 43:207-16. | Article | PubMed

9. Gossling J: Occurrence and pathogenicity of the Streptococcus milleri group. Rev Infect Dis 1988, 10:257-85. | Article I PubMed

10. lozzo RV: The biology of the small leucine-rich proteoglycans. Functional network of interactive proteins. J Biol Chem 1999, 274:18843-6. | Article I PubMed

11. Nikitovic D, Aggelidakis J, Young MF, lozzo RV, Karamanos NK and
Tzanakakis GN: The biology of small leucine-rich proteoglycans in bone pathophysiology. J Biol Chem 2012, 287:33926-33. | Article | PubMed

12. Vogel KG and Trotter JA: The effect of proteoglycans on the morphology of collagen fibrils formed in vitro. Coll Relat Res 1987, 7:105-14. | Article | PubMed

13. Sugars RV, Milan AM, Brown JO, Waddington RJ, Hall RC and Embery G: Molecular interaction of recombinant decorin and biglycan with type I collagen influences crystal growth. Connect Tissue Res 2003, 44 Suppl 1:189-95. | Article | PubMed

14. Hakkinen L, Strassburger S, Kahari VM, Scott PG, Eichstetter I, Lozzo $\mathrm{RV}$ and Larjava $\mathrm{H}$ : A role for decorin in the structural organization of periodontal ligament. Lab Invest 2000, 80:1869-80. | Article | PubMed

15. Waddington RJ, Roberts HC, Sugars RV and Schonherr E: Differential roles for small leucine-rich proteoglycans in bone formation. Eur Cell Mater 2003, 6:12-21; discussion 21. | Pdf | PubMed

16. Schonherr E, Sunderkotter C, Schaefer L, Thanos S, Grassel S, Oldberg A, lozzo RV, Young MF and Kresse H: Decorin deficiency leads to impaired angiogenesis in injured mouse cornea. J Vasc Res 2004, 41:499-508. | Article | PubMed

17. Fiedler LR, Schonherr E, Waddington R, Niland S, Seidler DG, Aeschlimann D and Eble JA: Decorin regulates endothelial cell motility on collagen I through activation of insulin-like growth factor I receptor and modulation of alpha2beta1 integrin activity. J Biol Chem 2008, 283:17406-15. | Article | PubMed

18. Bi Y, Nielsen KL, Kilts TM, Yoon A, M AK, Wimer HF, Greenfield EM, Heegaard AM and Young MF: Biglycan deficiency increases osteoclast differentiation and activity due to defective osteoblasts. Bone 2006, 38:778-86. | Article | PubMed

19. Sodek J: A comparison of collagen and non-collagenous protein metabolism in rat molar and incisor periodontal ligaments. Arch Oral Biol 1978, 23:977-82. | Article | PubMed

20. McCulloch CA, Lekic $P$ and McKee MD: Role of physical forces in regulating the form and function of the periodontal ligament. Periodontol 2000 2000, 24:56-72. | Article | PubMed

21. Wu Y, Cao H, Yang Y, Zhou Y, Gu Y, Zhao X, Zhang Y, Zhao Z, Zhang L and Yin J: Effects of vascular endothelial cells on osteogenic differentiation of noncontact co-cultured periodontal ligament stem cells under hypoxia. J Periodontal Res 2013, 48:52-65. | Article | PubMed

22. Landrygan-Bakri J, Wilson MJ, Williams DW, Lewis MA and Waddington RJ: Real-time monitoring of the adherence of Streptococcus anginosus group bacteria to extracellular matrix decorin and biglycan proteoglycans in biofilm formation. Res Microbiol 2012, 163:436-47. | Article | PubMed

23. Almeida RA, Luther DA, Nair R and Oliver SP: Binding of host glycosaminoglycans and milk proteins: possible role in the pathogenesis of Streptococcus uberis mastitis. Vet Microbiol 2003, 94:131-41. | Article | PubMed

24. Frick IM, Schmidtchen $A$ and Sjobring $U$ : Interactions between $M$ proteins of Streptococcus pyogenes and glycosaminoglycans promote bacterial adhesion to host cells. Eur J Biochem 2003, 270:2303-11. | Article | PubMed

25. Egesten A, Frick IM, Morgelin M, Olin Al and Bjorck L: Binding of albumin promotes bacterial survival at the epithelial surface. $J$ Biol Chem 2011, 286:2469-76. | Article | PubMed Abstract | PubMed Full Text

26. Wang Z, Flax LA, Kemp MM, Linhardt RJ and Baron MJ: Host and pathogen glycosaminoglycan-binding proteins modulate antimicrobial peptide responses in Drosophila melanogaster. Infect Immun 2011, 79:606-16. | Article | PubMed Abstract | PubMed Full Text

27. Edgell CJ, McDonald CC and Graham JB: Permanent cell line expressing human factor VIII-related antigen established by hybridization. Proc Natl Acad Sci U S A 1983, 80:3734-7. | Article | PubMed Abstract | PubMed Full Text

28. Bartie KL, Wilson MJ, Williams DW and Lewis MA: Macrorestriction fingerprinting of "Streptococcus milleri" group bacteria by pulsed-field gel electrophoresis. J Clin Microbiol 2000, 38:2141-9. | Article | PubMed Abstract | PubMed Full Text 
Waddington et al. Microbiology Discovery 2013,

29. Waddington RJ, Embery G and Hall RC: The influence of fluoride on proteoglycan structure using a rat odontoblast in vitro system. Calcif Tissue Int 1993, 52:392-8. | Article | PubMed

30. Tipler LS and Embery G: Glycosaminoglycan-depolymerizing enzymes produced by anaerobic bacteria isolated from the human mouth. Arch Oral Biol 1985, 30:391-6. | Article | PubMed

31. Nagamune H, Whiley RA, Goto T, Inai Y, Maeda T, Hardie JM and Kourai $\mathrm{H}$ : Distribution of the intermedilysin gene among the anginosus group streptococci and correlation between intermedilysin production and deep-seated infection with Streptococcus intermedius. J Clin Microbiol 2000, 38:220-6. | Article | PubMed Abstract | PubMed Full Text

32. Baker SM, Sugars RV, Wendel M, Smith AJ, Waddington RJ, Cooper PR and Sloan AJ: TGF-beta/extracellular matrix interactions in dentin matrix: a role in regulating sequestration and protection of bioactivity. Calcif Tissue Int 2009, 85:66-74. | Article | PubMed

33. Inkson CA, Ono M, Bi Y, Kuznetsov SA, Fisher LW and Young MF: The potential functional interaction of biglycan and WISP-1 in controlling differentiation and proliferation of osteogenic cells. Cells Tissues Organs 2009, 189:153-7. | Article | PubMed Abstract | PubMed Full Text

34. Tufvesson $E$ and Westergren-Thorsson G: Tumour necrosis factor-alpha interacts with biglycan and decorin. FEBS Lett 2002, 530:124-8. | Article | PubMed

35. Mochida $Y$, Parisuthiman D and Yamauchi M: Biglycan is a positive modulator of BMP-2 induced osteoblast differentiation. Adv Exp Med Biol 2006, 585:101-13. | Article | PubMed

36. Terranova VP and Wikesjo UM: Chemotaxis of cells isolated from periodontal tissues to different biological response modifiers. Adv Dent Res 1988, 2:215-22. I Article I PubMed

37. Matsuda N, Lin WL, Kumar NM, Cho MI and Genco RJ: Mitogenic, chemotactic, and synthetic responses of rat periodontal ligament fibroblastic cells to polypeptide growth factors in vitro. J Periodontol 1992, 63:515-25. | Article I PubMed

38. Silverio-Ruiz KG, Martinez AE, Garlet GP, Barbosa CF, Silva JS, Cicarelli RM, Valentini SR, Abi-Rached RS and Junior CR: Opposite effects of bFGF and TGF-beta on collagen metabolism by human periodontal ligament fibroblasts. Cytokine 2007, 39:130-7. | Article | PubMed

39. Santra M, Mann DM, Mercer EW, Skorski T, Calabretta B and Iozzo RV: Ectopic expression of decorin protein core causes a generalized growth suppression in neoplastic cells of various histogenetic origin and requires endogenous p21, an inhibitor of cyclin-dependent kinases. J Clin Invest 1997, 100:149-57. I Article I PubMed Abstract I PubMed Full $\underline{\text { Text }}$

40. Moscatello DK, Santra M, Mann DM, McQuillan DJ, Wong AJ and lozzo RV: Decorin suppresses tumor cell growth by activating the epidermal growth factor receptor. J Clin Invest 1998, 101:406-12. | Article | PubMed Abstract I PubMed Full Text

41. Schonherr E, O'Connell BC, Schittny J, Robenek H, Fastermann D, Fisher LW, Plenz G, Vischer P, Young MF and Kresse H: Paracrine or virus-mediated induction of decorin expression by endothelial cells contributes to tube formation and prevention of apoptosis in collagen lattices. Eur J Cell Biol 1999, 78:44-55. | Article | PubMed

42. Liew SM, Tay ST, Wongratanacheewin S and Puthucheary SD: Enzymatic profiling of clinical and environmental isolates of Burkholderia pseudomallei. Trop Biomed 2012, 29:160-8. | Pdf | PubMed

43. Macey MG, Whiley RA, Miller L and Nagamune H: Effect on polymorphonuclear cell function of a human-specific cytotoxin, intermedilysin, expressed by Streptococcus intermedius. Infect Immun 2001, 69:6102-9. | Article | PubMed Abstract | PubMed Full Text

44. Sukeno A, Nagamune H, Whiley RA, Jafar SI, Aduse-Opoku J, Ohkura K, Maeda T, Hirota K, Miyake $Y$ and Kourai $\mathrm{H}$ : Intermedilysin is essential for the invasion of hepatoma HepG2 cells by Streptococcus intermedius. Microbiol Immunol 2005, 49:681-94. I Article I PubMed

45. Gallagher JT, Turnbull JE and Lyon M: Patterns of sulphation in heparan sulphate: polymorphism based on a common structural theme. Int J Biochem 1992, 24:553-60. | Article | PubMed

46. LindahI U, Kusche-Gullberg $M$ and Kjellen L: Regulated diversity of heparan sulfate. J Biol Chem 1998, 273:24979-82. I Article I PubMed
47. Jockusch BM, Bubeck P, Giehl K, Kroemker M, Moschner J, Rothkegel M, Rudiger M, Schluter K, Stanke G and Winkler J: The molecular architecture of focal adhesions. Annu Rev Cell Dev Biol 1995, 11:379416. I Article I PubMed

48. Hoepelman Al and Tuomanen El: Consequences of microbial attachment: directing host cell functions with adhesins. Infect Immun 1992, 60:1729-33. | Article | PubMed Abstract | PubMed Full Text

49. Baron MJ, Wong SL, Nybakken K, Carey VJ and Madoff LC: Host glycosaminoglycan confers susceptibility to bacterial infection in Drosophila melanogaster. Infect Immun 2009, 77:860-6. | Article | PubMed Abstract | PubMed Full Text

\section{Citation:}

Waddington R J, Landrygan-Bakri J, Wilson M J, David W $\mathrm{W}$ and Michael L A O: Impact of bidirectional relationships between streptococcus anginosus group and host tissue matrix components on cellular activity: role in establishment of infection. Microbiology Discovery 2013, 1:4. http://dx.doi.org/10.7243/2052-6180-1-4 